\title{
ADVANTAGES AND LIMITATIONS OF THE DISCOUNTED CASH FLOW TO FIRM VALUATION
}

Sanja Vlaović Begović, Higher School of Professional Business Studies, Novi Sad Mirela Momčilović, Higher School of Professional Business Studies, Novi Sad Slobodanka Jovin, Higher School of Professional Business Studies, Novi Sad

\begin{abstract}
The assessment of the firm value by discounting cash flows may be achieved through free cash flow to equity ( FCFE) and free cash flow to the firm (FCFF). Although these two approaches will theoretically have the same results, in reality it is not often the case. The aim of this paper is to find the similarities and differences, and advantages and limitations of these two approaches to assess the firm value. The comparative review of these two models leads to the conclusion about the choice of more adequate approach to assess the firm value.
\end{abstract}

Key words: valuation, discounting, cash flows, rate of return, residual value, market value

JEL classification: 617, G32

\section{PREDNOSTI I OGRANIČENJA PROCENE VREDNOSTI PREDUZEĆA METODOM DISKONTOVANOG NOVČANOG TOKA}

Sažetak: Procena vrednosti preduzeća diskontovanjem novčanih tokova se može vršiti diskontovanjem novčanih tokova nakon servisiranja dugova i diskontovanjem novčanih tokova pre servisiranja dugova. Iako bi u teorijskom smislu ova dva pristupa trebalo da pruže iste rezultate, u praksi to često nije slučaj. Cilj ovog rada jeste da otkrije uzroke odstupanja procenjene vrednosti diskontovanjem novčanih tokova pre $i$ nakon servisiranja dugova, identifikuje uslove u kojima su procenjene vrednosti ekvivalentne $i$ oceni prednost korišćenja diskontovanja novčanih tokova nakon servisiranja dugova prilikom procene vrednosti preduzeća u zavisnosti od uslova poslovanja.

Ključne reči: procena vrednosti, diskontovanje, novčani tokovi, stopa prinosa, rezidualna vrednost, tržišna vrednost

\footnotetext{
*sanjavbegovic@gmail.com
} 


\section{INTRODUCTION}

Assessing the value of partial or total assets of a firm is a prerequisite for making important strategic decisions related to the sale, dividing or merging the firm. Next, the assessment of the firm value is done during privatization processes, when the shares of the firm are for the first time included in the list of stock exchange quotations, etc.

The firm value may be assessed by different methods, such as the method of book value, adjusted book value, assets, yield and liquidation value. The assessment of the value is usually determined using two methods to check the validity of the valuation. Then a yield method based on discounting cash flows is usually used (Vlaović Begović, Bolesnikov, Njegić, 2011). The aim of this method is to assess value according to the ability of the firm to generate free cash in future.

With the aim of more realistic planning of cash flows in the following period for the purposes of assessment, it is necessary to carry out the analysis of the firm in the recent period according to historical data, its position within the industry and macroeconomic data (Vlaović Begović, Bolesnikov, Njegić, 2011). The financial analysis provides information on yield power of the firm, its assets position, liquidity, solvency and indebtedness. The method of discounted cash flows determines the value of the firm depending on the expected cash flows and equity prices.

There are two cash flows and thus two approaches to assess the value of the firm - free cash flow to equity (FCFE) and free cash flow to the firm (FCFF). In the following part of the paper there will be the presentation of advantages and limitations of the application of these two approaches to assess the value of the firm as well as the choice of a more adequate approach.

\section{THEORETICAL BASIS OF THE ASSESSMENT OF THE FIRM VALUE BY DISCOUNTING CASH FLOWS}

The discounted free cash flow to equity model for valuation requires (Rodić \& Filipović, 2010):

- $\quad$ projection of free cash flow to equity,

- discounted rate calculation (return on equity),

- discounting the projected cash flows,

- determining the growth rate,

- calculating the residual value of the firm,

- $\quad$ discounting the residual value of the firm,

- $\quad$ adding the present value of cash flows and present value of the residual to obtain the value of the equity. 
The free cash flow to equity means a free cash flow which is available to the holders of ordinary shares after all operational expenses of interests and principal are paid and after necessary investments in net working capital and fixed assets are achieved (Stowe, Robinson, Pinto, \& MeLeavey, 2002). In order to assess how much remains available to the holders of ordinary shares the starting point is usually net profit which is adjusted for the investments of the firm. In future an increase of cash flows is expected on the basis of investment (Zakić, 2011, p.56), however, at the time of valuation investments are an outflow of cash. Depreciation calculated for the fixed assets does not represent actual cash expenditures. Since depreciation is deduced while calculating net profit, it must be added back during the calculation of free cash flow. Capital expenditures are adjusted for the amount of depreciation and thus net capital expenditures of the firm are obtained. Net profit needs to be adjusted for the change in net working capital. An increase in net working capital leads to a fall in cash and vice versa, a fall in net working capital provides more cash for shareholders. In order to calculate free cash flow to equity, both new and old debts must be taken into account. Every new debt of the firm contributes to an increase in cash. Net indebtedness of the firm represents the difference between new debts and the outstanding debt paying (Damodaran, 2002). Net profit is adjusted for that amount.

Free cash flow to equity $=$ Net profit + Depreciation - Investment in fixed assets (capital expenditures) - Change in net working capital + New loans Outstanding loans paying

The discounted free cash flow to equity is performed by the rate of return on equity calculated by CAP (Capital Asset Pricing) model or build-up method. CAP model requires information on risk-free return rate, the value of Beta factor for a given firm (which is used to measure sensitivity of the return of the company compared to the total market yield) and the premium of market risk. However, in the conditions of undeveloped capital market and for the firms whose shares are not traded at the stock exchanges, the rate of return can be calculated by the build-up method which requires information on risk-free rate of return, rate of investment risk in a given firm and rate of investment risk in the country where the firm operates. Respecting the principle of permanence of operating, the residual value of the firm is calculated, and for this process the growth rate in the period after the last year of the projection of cash flows is needed. Discounting is also done by the rate of return on equity. By adding discounted cash flows and discounted residual period, the value of equity is obtained.

In the case of firm valuation by discounted free cash flow to the firm, it is necessary to do the following (Rodić \& Filipović, 2010): 
- $\quad$ project free cash flow to the firm,

- $\quad$ calculate discount rate (weighted average cost of capital),

- discount the projected cash flows,

- determine the growth rate,

- calculate the residual value of the firm,

- discount the residual value of the firm,

- $\quad$ the value of the debt at the date of the valuation should be deduced from the sum of the present value of projected cash flows and the present value of the residual so the value of the equity will be obtained.

The free cash flow to the firm represents a cash flow available to those who provided shareholders and creditors with the capital necessary for business operations, and after all necessary investments in net working capital and fixed assets are conducted (Stowe, Robinson, Pinto, \& MeLeavey, 2002). This is also a difference between free cash flow to equity and free cash flow to the firm and new projected debts. Namely, free cash flow to the firm does not take cash expenditures for interest and debt into account, whereas they are not neglected in the case of calculating free cash flow to equity (Damodaran, 2002).

Free cash flow to the firm $=$ EBIT $(1-$ tax rate $)+$ Depreciation - Investment in fixed assets - Change in the net working capital

For the purposes of discounting free cash flow to the firm, the price of all financing sources to the firm should be calculated by using the weighted average cost of capital (WACC), which takes into account the structure of the source unlike discounted free cash flow to equity which use the price of equity. Therefore, the addition of the present value of the projected free cash flow to the firm and the present value of the residual does not lead to the direct calculation of the equity value, as in the previous approach, the value of the debt on the date of the valuation is deduced but from the obtained sum in order to get the value of the equity.

\section{COMPARATIVE OVERVIEW OF THE RESULTS OF THE VALUATION BY DISCOUNTED FREE CASH FLOWS TO EQUITY AND FREE CASH FLOW TO THE FIRM}

The listed methodologies will be applied in the valuation of the real company whose shares are listed at the Belgrade Stock Exchange. 


\subsection{THE ASSESSMENT OF THE FIRM VALUE BY DISCOUNTED FREE CASH FLOWS TO EQUITY}

According to the analysis of financial reports, macroeconomic data and the analysis of the industry in which the given company operates, there is a projection of the net free cash flow to equity in the next five years:

Table 1

The projection free cash flow to equity

in 000 RSD

\begin{tabular}{|c|c|c|c|c|c|}
\hline Year of the projection: & First & Second & Third & Fourth & Fifth \\
\hline 1. Net profit & 247,057 & 294,957 & 348,788 & 405,860 & 431,718 \\
\hline 2. Depreciation & 182,492 & 182,492 & 182,492 & 182,492 & 182,492 \\
\hline $\begin{array}{l}\text { 3. Investment in net working } \\
\text { capital }\end{array}$ & 34,741 & 18,501 & 20,811 & 21,298 & 8,764 \\
\hline 4. The outstanding loan paying & 269,418 & 156,508 & 176,357 & 198,724 & 223,928 \\
\hline $\begin{array}{l}\text { 5. Free cash flow to equity }(1+2- \\
\text { 4) }\end{array}$ & 125,390 & 302,440 & 334,112 & 368,330 & 381,518 \\
\hline
\end{tabular}

Note: Based on (Procena vrednosti preduzeća, Rodić, Filipović, 2010, Beograd: Asimex.)

In the given company there will be neither investment in the plants, equipment and machinery nor new debts in the next five years. In order to calculate rates of return on equity the build-up method will be used so the following information is needed:

- $\quad$ rate of return on risk-free investment $-4.5 \%$ (Realna stopa prinosa na ulaganja bez rizika za period oktobar 2001 - april 2002., 2001) - Real rate of return on risk-free investment determined by the Agency for Privatization ${ }^{1}$, which is according to the Decision on methodology for capital and assets valuation in the Republic of Serbia used by the enterprises entering the process of privatization or undergoing statutory changes.

- $\quad$ rate of investment risk in the firm $-9.5 \%$ - the build-up method is used according to the Decision on methodology for capital and assets valuation in the Republic of Serbia. Due to its high range, this paper presents only the calculated rate of investment risk but not the procedure of its calculation.

The rate of return on equity is $4.5 \%+9.5 \%=14 \%$. In order to obtain discount rate, it is needed to include the rate of interest risk in the country where the firm

\footnotetext{
${ }^{1}$ The data from 2001 are used, since the Agency for Privatization did not determine afterwards the rate of return on investment or risk premium of investing in the Republic of Serbia.
} 
operates $-7 \%$ (Premija za rizik na ulaganje u SRJ za period oktobar 2000 april 2001., 2001). Thus the calculated discount rate is $21 \%$ whereby the projected cash flows are at the level of the present value, as presented in Table 2:

Table 2

Discounted free cash flow to equity

\begin{tabular}{llll}
\hline Year & Cash flow (I) & Discount factor (II) & $\begin{array}{l}\text { Present value } \\
(I \times I I)\end{array}$ \\
\hline 1 & 125,390 & 0.8264463 & 103,628 \\
\hline 2 & 302,440 & 0.6830135 & 206,571 \\
\hline 3 & 334,112 & 0.5644739 & 188,598 \\
\hline 4 & 368,330 & 0.4665074 & 171,829 \\
\hline 5 & 381,518 & 0.3855433 & 147,092 \\
\hline $\begin{array}{l}\text { Total } \\
(1+2+3+4+5)\end{array}$ & & 817,717 \\
\hline
\end{tabular}

Note: Based on (Procena vrednosti preduzeća, Rodić, Filipović, 2010, Beograd: Asimex.)

The calculation of residual value according to the cash flow in the last projected year $(381,518$ thousand dinars), growth rate $(1 \%)$, and discount rate $(21 \%)$ is presented as follows:

$\frac{381,518 \times 1.01}{0.21-0.01}=1,926,666$ thousand RSD

Then there is discounted residual value:

$1,926,666 \times \frac{1}{(1+0.21)^{6}}=613,896$ thousand RSD

Finally, the calculation of estimated equity value is obtained by adding the present value of the projected free cash flow to equity and the present value of the residual, that is:

Return value of the firm $=817,717+613,896=1,431,613$ thousand $\mathrm{RSD}$ (or 1.43 billion RSD)

\subsection{THE ASSESSMENT OF THE FIRM VALUE BY DISCOUNTED FREE CASH FLOW TO THE FIRM}

Table 3 shows the projection of free cash flow to the firm in the next five years. 
44 I ADVANTAGES AND LIMITATIONS OF THE DISCOUNTED CASH FLOW TO FIRM VALUATION

Table 3

The projection of free cash flow to the firm

in $000 R S D$

\begin{tabular}{llllll} 
Year of the projection: & First & Second & Third & Fourth & Fifth \\
\hline 1. EBIT (1-tax item.) & 344,702 & 368,973 & 404,939 & 441,883 & 445,056 \\
\hline $\begin{array}{l}\text { 2. Depreciation } \\
\begin{array}{l}\text { 3. Investment in net working } \\
\text { capital }\end{array}\end{array}$ & 182,492 & 182,492 & 182,492 & 182,492 & 182,492 \\
\hline $\begin{array}{l}\text { 4. Cash flow to the firm (1+2-3) } \\
44,741\end{array}$ & 18,501 & 20,811 & 21,298 & 8,764 \\
\hline
\end{tabular}

Note: Based on (Procena vrednosti preduzeća, Rodić, Filipović, 2010, Beograd: Asimex.)

To calculate the average weighted cost of capital, the following information is needed:

- $\quad$ rate of return on equity $-14 \%$

- the price of debt $-12 \%$

- the share of equity in the total financing sources $-71.67 \%$

- the share of debt in the total financing sources $-28.33 \%$

- tax rate $-10 \%$

$\mathrm{WACC}=(71.67 \times 0.14)+(28.33 \times 12) \times(1-0.10)=13.09 \%$

To obtain the discount rate it is necessary to include the rate of investment rate in the country in which the company operates: $13.09 \%+7 \%=20.09 \%$. Therefore, the discount rate of $20.09 \%$ is used to assess the firm value by discounted free cash flow to the firm. The present value of the projected free cash flow to the firm is calculated in Table 4.

Table 4

Discounted free cash flow to the firm

in 000 RSD

\begin{tabular}{llll}
\hline Year & Cash flow $(I)$ & Discount factor $(I I)$ & Present value $(I \times I I)$ \\
\hline 1 & 492,452 & 0.8327088 & 410,069 \\
\hline 2 & 532,964 & 0.6934039 & 369,559 \\
\hline 3 & 566,620 & 0.5774036 & 327,169 \\
\hline 4 & 603,077 & 0.480809 & 289,965 \\
\hline 5 & 618,784 & 0.4003739 & 247,745 \\
\hline \multicolumn{7}{l}{ Total present value of net cash flow $(1+2+3+4+5)$} & $1,644,507$
\end{tabular}

Note: Based on (Procena vrednosti preduzeća, Rodić, Filipović, 2010, Beograd: Asimex.) 
The calculation of the residual value according to the net cash flow in the last projected year $(618,784$ thousand dinars), growth rate $(1 \%)$, and discount rate $(20,09 \%)$ is presented as follows:

$$
\frac{618,784 \times 1.01}{0.2009-0.01}=3,273,820 \text { thousand RSD }
$$

Then, there is a discounted residual value:

$$
3,273,820 \times \frac{1}{(1+0.2009)^{6}}=1,091,475 \text { thousand RSD }
$$

The firm value is obtained by deducing the debt value on the date of the assessment from the sum of the present values of the projected free cash flow to the firm and residuals:

Return firm value $=1,644,507+1,091,475-1,024,935=1,711,047$ thousand RSD or 1.71 billion RSD

The total number of issued shares of the given company is 117,301 . Having this in mind, and according to the calculated return firm value, the value of one share can be calculated in the following manner:

- $\quad$ Value per share calculated according to the return firm value obtained by discounted free cash flow to equity is: $1,431,613,000 / 117,301=12,205$ dinars

- $\quad$ Value per share calculated according to the return firm value obtained by discounted free cash flow to the firm is:

$$
1,711,047,000 / 117,301=14,587 \text { dinars }
$$

At the moment of the valuation of the firm, the market value of the share of this firm at the Belgrade Stock Exchange was 12,199 dinars.

\section{CONCLUSION}

According to the presented elements necessary for determining the firm value by FCFE or FCFF, it can be seen that both approaches have the same aim and it is to determine the value of equity of the firm. Likewise, there are other differences related to the procedure of the valuation of the firm by the mentioned approaches:

- $\quad$ structure of cash flows (FCFE and FCFF)

- discount rate (rate of return on equity and average weighted cost of capital)

- $\quad$ determining the value of equity (directly and indirectly). 
The noticed differences bring to advantages but also to limitations in the approaches of assessment.

The advantage of approach to the valuation of the firm by discounting free cash flow to equity is in the detailed design of the balance sheet and income statement which include all future inflows and outflows of funds. In this way, the projected balance is largely brought to real future balances. The result of estimates based on projected cash flows contributes to more accurate and more realistic value of the company.

However, this advantage may also be a limitation in the application of the free cash flow to equity model if the projection of cash flow is not done properly. The limitation is the difficulty of the prediction of the structure of financial sources for companies. The difficulty is reflected in the definition of the outstanding debt repayment plans as well as the projection of new debt.

The prediction of interest cost may represent another limitation. The assessor's choice of the dynamics of the payment of loan obligations influences the source of financing and the amount of interest cost. Namely, the assessor may decide to project loan payment in decreasing or the same annuities. Also, it is possible to have payment of interest annually or after six months rather than monthly so it leads to different interest cost. The amount of interest cost influences the amount of net profit in every year of the projection. The amount of net profit in every year of the projection reflects on the total assessed value of the company calculated by discounted free cash flow to equity. Likewise in the structure of financing source there can be indebtedness to the linked business entities that are approved by non-realistic low interest rate. In that case it is necessary to assess such debt by the valid market interest rate.

The advantages of the valuation of the firm by discounting free cash flow to the firm is reflected in its simplicity and velocity of the valuation compared to the approach to assess the value by discounted free cash flow to equity. The simplicity of the approach comes from neglecting cash flows bound to debt and interest, which at the same time means neglecting their changes during the period of the projection. Subsequently, there is a limitation while the calculation of the average weighted cost of capital because the balance on the date of the assessment is taken for the share of own and borrowed sources in the total financing sources. There is the change neglect of their relation in the projected period occurred due to the outstanding debt paying or new debt. Likewise, the price of the borrowed sources necessary for the calculation of the average weighted cost of capital represents the cost of the debt on the date of the assessment. The cost of the debt is determined according to the average 
interest rate on interest-bearing liabilities. When in the period of the projection some debts are paid or a new debt occurs, the average weighted interest rate changes. However, this change is not taken into account during the valuation by discounted free cash flow to the firm, which reflects on the assessed firm value.

Taking into account the advantages and limitations of the valuation of the company by FCFE and FCFF, the authors of the paper are in favour of the view that the valuation of the company should be made using the model of discounted free cash flow to equity. In addition, this model takes into account the amount of cash flows allocated to the principal and interest, loan maturity, amount and any change in the cost of the debt and the time value of money in interest-bearing liabilities, which leads to the conclusion that this model is a more realistic assessment of the results compared to free cash flow to the firm.

\section{REFERENCES}

Damodaran, A. (2002). Investment Valuation: Tools and Techniques for Determining the Value of Any Asset. New York: John Wiley \& Sons.

Premija za rizik na ulaganje u SRJ za period oktobar 2000 - april 2001. Službeni glasnik RS. No.60 (2001).

Realna stopa prinosa na ulaganja bez rizika za period oktobar 2001 - april 2002. Službeni glasnik RS. No.60 (2001).

Rodić, J., Filipović, M. (2010). Procena vrednosti preduzeća. Beograd: Asimex.

Stowe, J., Robinson, R., Pinto, J., \& MeLeavey, D. (2002). Analysis of Equity Investments: Valuation. Charlottesville: Association for Investment Management and Research.

Vlaović Begović, S., Bolesnikov, D., \& Njegić, J. (2011). The importance of value assesment of enterprise by discounting of cash flows for investor. IV International Conference Eurobrand (pp. 255-265). Vršac - Temišvar: TQM Center.

Zakić, V. (2011). Dodata ekonomska vrednost kao merilo generisanja vrednosti za akcionare. Škola biznisa, (1) 53-61.

Primljeno: 06.03.2013.

Odobreno: 25.03.2013. 